\title{
How to Carry Out a Democratic Ethnobotanical Study
}

\author{
Pedro Crepaldi Carlessi ${ }^{1 *}$ \\ ${ }^{1}$ Centro de Estudos de Religiosidades Contemporâneas e das Culturas Negras, University of São Paulo, São Paulo, Brazil. \\ *pccarlessi@gmail.com
}

\begin{abstract}
This contribution aims to share some experiences and methodological considerations that arose during an ethnobotanical research project with an Afro-Brazilian religious community in the city of São Paulo, Brazil. By presenting ontological features of plants used in religious practices, and the ways relations are created within this religious cosmology, this work opens a discussion about the political commitments of doing contemporary ethnobotanical science. When the ways of being and living in communities considered "traditional" - here referring to Afro-Brazilian religious communities, and specifically to the Umbanda Afro-Brazilian religion-are treated as equally valid, questions arise about the reaches of our own scientific practices, creating possibilities to construct practices and policies that preserve these communities' vitality in the face of the overwhelming imposition of colonialism. In this sense, ethnobotanical research is at an analytical crossroads that can give the field an advantage over the political paralysis of the sciences and over the clandestine politicization of science as the spokesperson for a singular nature. These considerations lead to self-reflection on scientific expertise and democratic ways of producing knowledge about plants in plural cultural contexts.
\end{abstract}

Received March 7, 2019

OPENठACCESS

Accepted September 9, 2019

DOI 10.14237/ebl.10.1.2019.1547

Published December 4, 2019

Keywords Cosmopolitics, Ethnobotany, Science studies, Sacred leaves, Umbanda

Copyright (c) 2019 by the author(s); licensee Society of Ethnobiology. This is an open-access article distributed under the terms of the Creative Commons Attribution-NonCommercial 4.0 International Public License (https://creativecommons.org/licenses/by-nc/4.0), which permits non-commercial use, distribution, and reproduction in any medium, provided the original author and source are credited.

\section{Introduction}

In early 2014, I began an ethnobotanical study among an Afro-Brazilian religious community in the city of São Paulo, Brazil. At that time, two interests guided my research: first, to learn about the flora employed in Umbanda ${ }^{1}$ religious practices; and second, to analyze the scope of rituals observed during ethnographic fieldwork. Therefore, the approach established at the outset of the study, both by the academics accompanying me and by the Umbanda practitioners who kindly welcomed research into their temple, was to proceed by identifying and classifying plant specimens according to methods of scientific knowledge production.

At the time, the temple was undertaking measures to safeguard its intangible cultural heritage in preparation for two celebratory occasions: the $60^{\text {th }}$ anniversary of the terreiro' $\mathrm{s}^{2}$ foundation (as well as a change of address upon occupying a new facility), and an homage to the community's present religious leader, who had completed 18 years of leadership. To establish a registry of its cultural heritage, members of the community created a work group, occasionally inviting external colleagues to participate. Over two years, the work group produced several audiovisual and printed materials, such as booklets including ceremonial chants, celebration calendars, interviews with longstanding and newer community members, photographic exhibitions of ceremonies and important historical moments, a documentary (unfinished at the time of writing), and a virtual platform to make these materials available to the public.

The project was called "a teia" (the web), as the group understood that the history they wished to (re) tell- that of the Circulo de Irradiações Espirituais de São Lázaro (CIESL; Saint Lazarus Spiritual Irradiation Circle), coordinated by Pai Alexandre-actually involved several other interwoven circles that encompass both human and non-human stories. In order to capture the concept of a "circle" as describing a collective, it must be emphasized that Afro-Brazilian religious cosmologies consider beings other than humans - such as trees, plants, seas, rivers, 
oceans, cemeteries, forests, and even the ground and walls of the temple - to play active social roles in daily life. As I was told by Pai Alexandre in the first months of fieldwork, "in an Umbanda temple, everything speaks."

I did not participate in this initial work group. My involvement started in a subsequent phase when the plant registry was being established. Nevertheless, when I presented my research proposal to the terreiro leadership, they asked me to make the scientific names of the plants available to the work group. Once the community was established in their new facility with a much larger garden, they became interested in using this nomenclature in a brochure for newcomers to the religion, as well as to produce signs conveying both the local and corresponding scientific names of each plant in their garden.

By building knowledge and information within and about the terreiro, the search for scientific legitimacy is a feature of Umbanda's historical trajectory. This extends back to the 1920s and 1930s, when middle-class Kardecists, a group of Spiritists emerging from the metropolis of southern and southeastern Brazil, began to infuse their practices with Afro-Brazilian religious elements (Silva 2005). Through this process, ritual elements that were previously marginalized, such as the use of alcoholic drinks, tobacco, and other offerings, were either banned or justified. These judgements were based on the moral standards of the dominant classes at the time, who employed the powerful discourses of modern sciences to form legitimate discourses of their own. Indeed, the biologists accompanying my research viewed the botanical taxonomy work as a prerequisite to scientific activity. Without it my research would be fated to failure, as it would not offer a valid and scientifically assured reference for the plants being presented to me by community members.

\section{Methods and Dilemmas}

The "scientific names" were employed by both parties aiming at a nomenclature intended to be universal. As such, this work not only required me to carry around a field notebook-the traditional companion of ethnographic practice-but also to employ established methods of botanical collection. I chose the "dry method" (Fidalgo and Bononi 1989), in which collected plants are placed in a standard field press and dehydrated in an herbarium oven. Every time I recorded a new plant in my field notes, I collaborated with the terreiro members to help familiarize me with it. I then collected specimens, in whole or in part, and took them to the São Paulo City Herbarium to be taxonomically identified and classified.

There is no doubt that scientific knowledge is hegemonic (Agrawal 1995; Carneiro da Cunha 2007); after all, it is even employed in religious discourses. This hegemony is signaled by the term itself, science, that directly refers to modern Western knowledge, while references to other forms of knowledge take the prefix ethno-. To be democratic, we must say that every science is necessarily ethnoscience. However, as observed by Oliveira (2012:17), this qualitative distinction is still used to enlarge the gap between "us" and "them", where only "them" is marked by ethno-. This prefix, at the most popular sense, serves as a caveat that implicitly diminishes the value of the term it qualifies, at least in the eyes of contemporary science.

It follows from these observations that the demands to include scientific nomenclature, which came from both the scientific and religious parties, led me to a dangerous theoretical-methodological position. As I accommodated the requirements of botanical science, I implicitly adopted the synthetic category "plant" as conceptualized within a scientific cosmovision. In this way, I would be restricted to translating the meanings given by Umbanda practitioners into terms recognizable within botanical discourse.

The Espada-de-São-Jorge, for example, is recognized among botanists as Sansevieria trifasciata. The plant is always given the same name in CIESL; however, depending on the plants growing around it, the location, time, and prayers done during the collection, the plant undergoes ontological changes, such that each Espada-de-São-Jorge becomes very different from others. Not only does the plant's meaning shift in the ritual, but more importantly, so does the nature of its existence in the world. As such, these plants can be rendered either dispensable or integral to religious services according to the relational system that characterizes them. Following the advice of my colleagues in the terreiro, I collected two samples considered to be distinct, but considered by my botanist colleagues as the same species of "plant".

The problem with this approach is that it attempts to legitimize local knowledge by appealing to scientific concepts, trying to make the former comparable and 
compatible with a Western scientific framework. This practice is at the very least anthropocentric and limiting, granting science the right to define reality without questioning its claims. This is incompatible with the goals of any analysis that aims to be democratic, or at least honest, about the different ways of being in the world.

\section{Between the Terreiro and the Herbarium}

The movement between the terreiro and the herbarium, however, was interesting, as each new plant presented to the botanists triggered many exchanges. There were often small crowds of scientists interested in saints, herb baths, and the whole new world that these plants were bringing into the lab. This was a key moment in my research. The botanists were astonished with the religious flows carried by these plant samples, making them very different from the other plants in their collections.

Similarly, as the collection proceeded, members of the terreiro became interested in my academic practice. Taxonomic practice requires collection of plants bearing flowers or fruits, structures that are indispensable to botanists' work. However, these structures are less often considered in the classification systems used in Afro-Brazilian religious practices, which mainly focus on leaf characteristics. Furthermore, the botanical method was not able to acquire plants as they were presented to me. In the Umbanda religion, plants have auras and accompanying gods, which are realities that field presses and newspaper sheets used in botanical research do not capture. The term "realities" is appropriate because this experience is irrefutable: the invisible universe usually attributed to "culture" is, to Afro-Brazilian practitioners, part of what scientists call "nature." In Afro-Brazilian religious cosmology, the plants do not end at the surface of their leaves, but instead permeate and extend beyond the material universe or "kingdom plantae" (Carlessi 2015).

Beyond simply an exercise in how we categorize the world, these observations reinforce the argument that both the ideas of "nature" and "culture" are fluid and elaborated differently by particular social groups, including the scientific community. In a series of publications, Bruno Latour demonstrates (Latour 1987, 1999; Latour and Woolgar 2013) how laboratory practices interpret the world in order to understand and explain "nature," transforming the reality of material things not only epistemologically, but also ontologically. A careful look at ethnobotani- $\mathrm{cal}^{3}$ practice- the entries in fieldwork notebooks, the selection of specimens, collection, transportation, separation, sanitization, drying, and finally classification, now as a taxon-shows how the botanical method gradually transforms plant reality, ruling out some attributes of the world described by the interviewees during the fieldwork as "culture." Toward this end, at the herbarium, an extensive network of microscopes, magnifying glasses, pruning shears, field presses, herbarium ovens, and cataloging sheets is used to elaborate a new meaning for the plants under study, cutting away parts of the previous meanings (or relational properties) they held in their relationships with Afro-Brazilian religious practitioners.

\section{Ethical Agreements and the Production of Legitimacy}

Efforts to preserve the terreiro's ways of being were compromised by the Western official mechanisms that had to be observed to produce social legitimacy. In order to conduct this research, it was necessary to comply with laws concerning what the Brazilian state terms "traditional knowledge associated to genetic property"4. In the year before the fieldwork began, the study proposal was presented to Pai Alexandre and a statement of consent was agreed. However, the consent that ultimately allowed this research to be conducted was not granted by the religious leader himself, but by one of the entities that manifest in his body, through the process of spiritual incorporation. Here I present an excerpt from the meeting in which we discussed this agreement:

Pai Alexandre: Have you already talked to Sen Sete? [referring to Exú Sete Sepulturas, one of the leading spiritual entities in the terreiro].

Me: Not yet. Nevertheless, I spoke with Maria Padilha [another important entity in the religious community].

Pai Alexandre: And what did she say?

Me: She said that if I do not do a good job she will kill me (laughs).

Pai Alexandre: Well, now it's definitely authorized!

This excerpt illustrates the issue of what kind of social legitimacy must be employed in a democratic study concerning different ideas of what we call "social." Contracts, as legalized forms of exchange, create legalized subjects to represent collectives. In 
Brazil, although the Afro-Brazilian communities' ways of living are legally recognized by the 1988 Federal Constitution, scientific research carried out in their territories and others generally described as "traditional" faces the challenge of adjusting legality to legitimacy, especially in communities whose notion of "social" is more extended than usually recognized. Confined by a Western political ontology developed in the seventeenth century, how can we deal with this contradiction without being reductionist?

Whenever they were materially present through the process of incorporation, I sought to introduce the research to the entities who, together with humans, lead this religious community. I tried to include them in the research in the same way I did with the humans. I presented the documents recognized by the Brazilian state as tools of legitimacy. These were mostly replaced by agreements imposed by the entities themselves, reflecting their unique negotiating power. I tried to respect them as parties to negotiation, adopting a political attitude of enhanced cooperation. To build a political ontology, it is necessary recognize collectives in their true context instead of finding them ready-made.

\section{Making Democracy Among Cosmologies}

I believe it is necessary to go beyond simply pointing out differences between the ways of being adopted by Afro-Brazilian and scientific communities-a first effort in building a democratic ethnobotanical study-and construct practices and policies that preserve these communities from the overwhelming imposition of Westernism.

One of the current challenges in Brazilian environmental law, from the standpoint of AfroBrazilian religious communities, is guaranteeing access to public green areas for religious practices. Contact with conserved flora is essential for these practices, and Afro-Brazilian communities have legitimately demanded this legal protection from the state. However, such access has been controversial and sometimes criminalized based on claims and complaints that offerings lead to the degradation of these areas. This amounts to an institutionalized mechanism of environmental racism (Moutinho-DaCosta 2013). Indeed, the notion of "ecology" in these communities is broader than Westerners generally recognize. Ethnobotanical studies have shown that the daily practices of Afro-Brazilian religious communities are related to the growth and preservation of metropolitan green areas (Rêgo 2006;
Voeks 1997). Innovative paths to environmental education and management practices have also been built based on these groups' worldviews (Rocha et al. 2014).

Likewise, the Afro-Brazilian conceptualization of the body and plant-based healing (Amaral 2009; Barros and Napoleão 1999; Carlessi 2017) is in line with international demands for expansion of health care approaches beyond mainstream practices. In Brazil, ethnobotanical studies focusing on this issue offer possibilities for recovering neglected knowledge of Afro-Brazilian practices, as well as helping to build more democratic public health policies (Castor 2015; Mello and Oliveira 2013). These efforts not only pose epistemological and ontological challenges, but they also have ethical and political dimensions.

Contemporary authors have sought to demonstrate how the theoretical movements in the social sciences and humanities, which advocate for an ontological approach to human-nonhuman relations, can engage with the field of ethnobiology. They argue that such an encounter would be fruitful in expanding the possibilities and scope of this research area.

Daly et al. (2016) discuss how human-plant relations might be re-conceptualized and theorized using a "botanical ontology" approach. They demonstrate how radically divergent human-plant lifeworlds are constructed in different societies. In the same line of thought, Ludwig (2018) shows that the focus of ethnobotanical research has changed since the early 1980s, shifting the debate about folkbiological cognition to other institutions and fields of knowledge. However, through a contemporary and highly influential theoretical framework, Ludwig demonstrates how a novel conversation about cognition has fueled research about human-plant relationships in different societies from an integrative perspective. Following the insights produced by this reanalysis of the classical conceptual frameworks, DeVore (2017) analyzes ritualized instructions for harvesting oleoresin or "oil" from the copaiba tree in Brazil. This work demonstrates how plants can be sensitive to human language and intentionality, thus demonstrating certain attributes that in Western worldviews are otherwise thought to be unique to humans.

Building on these observations, the methodological experiences shared in this research show that the ways of being and living in communities considered "traditional"-here referring to Afro-Brazilian 
religious communities, and specifically to the Umbanda Afro-Brazilian religion-when treated as equally valid, enable self-reflection about our own scientific practices and assumptions. In this sense, ethnobotanical research is at an analytical crossroads that can give the field an advantage over the political paralysis of the sciences and over the clandestine politicization of science as the spokesperson for a singular nature.

\section{Conclusion: Fieldwork Does Not Fit in the Field Press}

In this contribution, I have tried to revisit the paths covered in the development of this ethnobotanical research, sharing dilemmas and reflections related to the construction of a research study that respects many ways of being in the world.

In order to carry out a democratic ethnobotanical study, I addressed a set of premises that are politically related to the choice and application of methods. These must be politically committed to the particular cosmologies under study.

I suggest that any attempt to conduct a democratic ethnobotanical study begins by questioning the possibilities and scope of the discipline itself. As shown in this work, even the material boundaries of a plant's body, as they are understood in western thought, did not fit precisely into the Umbanda's conception of a plant's existence. Perhaps instead of compressing ethnobotanical concepts into comparative models appropriate for taxonomical science, we can create new analytical models that forgo the universality characteristic of modern thought, and embrace more of the particularities that the world constantly presents.

Moreover, instead of merely translating the Umbanda practitioner's knowledge into Western scientific language, I insist on a stronger recognition and validation of the Umbanda practitioners' worldviews, and thus a democratization and leveling of hierarchies between worldviews.

This fieldwork was democratized in its day-to-day processes of gaining consent, not only from the human practitioners, but from the entire social network (for example, from religious entities). This widened the circle of stakeholders and consent-givers to the various social beings that take part in the concretely lived reality of these communities.

The cosmopolitical ties of ethnobotanical practices are what is being democratized. If the "reality" of what we generally call "nature" continues to be defined through the optics of modern science, then ethnobotanical work might commit to deconstructing this model of a singular world, merely interpreted in different ways in different cultural contexts. As we question the terms, categories, and alliances of the scientific endeavor, we find that science is yet another ethno-science that can be disassembled and analyzed. Such an attitude is required for a deeper revision of the assumptions of the scientific endeavor, and for establishing democratic parity among sciences that are all ethnosciences.

\section{Notes}

${ }^{1}$ Umbanda is one of the most popular Afro-Brazilian religions. Its practices merge elements related to the worship of orishas, Brazilian popular Catholicism, and healing practices of Brazilian natives. The Umbanda became organized in its current form at the beginning of the twentieth century and spread from the Brazilian southeast to the entire national territory. Today, the Umbanda religion can be found in many countries in the Americas and Europe.

${ }^{2}$ Afro-Brazilian religious temple.

${ }^{3}$ Although this category has varied in the literature, the "human-plant" relationship continues to prevail. Ethnobotany has been shown to be a specific form of knowledge production operated by researchers interested in the cultural nuances attributed to plants or in the biological particularities of plants used by different human groups.

${ }^{4}$ According to item II of article 2 of Brazilian Law 13,123, May 20, 2015: "information or practices of indigenous groups, traditional communities or traditional farmers regarding the properties or direct or indirect uses associated with genetic heritage." Traditional knowledge associated with genetic heritage is related to nature, living beings and the environment, and is part of the ancestral practice of certain ethnic groups. This knowledge integrates the Brazilian cultural heritage and, in the scope of scientific research, is accessed through a technical judicial process that safeguards the rights and benefits associated with knowledge of real or potential value. This assurance, however, is controversial when hybrid notions such as tradition, nature, and communityamong many others-are used without considering the cosmopolitical disparities that these terms may assume. 


\section{Acknowledgments}

To my colleagues at the São Paulo Herbarium who kindly welcomed part of this research and taught me a lot. Special thanks to Sumiko Honda and Ricardo José Francischetti Garcia.

\section{Declarations}

Permissions: IPHAN authorization number 01450.004819/2014-14 and Federal University of São Paulo ethics committee approval for fieldwork number 610.407.

Sources of funding: None declared.

Conflicts of Interest: None declared.

\section{References Cited}

Amaral, R. 2009. Xirêl!: O Modo de Crer e de Viver no Candomblé. Pallas, Rio de Janeiro, Brazil.

Agrawal, A. 1995. Dismantling the Divide Between Indigenous and Scientific Knowledge. Development and Change 26:413-439. DOI:10.1111/j.14677660.1995.tb00560.x.

Carneiro da Cunha, M. 2007. Relações e Dissensões Entre Saberes Tradicionais e Saber Científico. Revista USP 75:76-84.

Carlessi, P. C. 2017. Jeitos, Sujeitos e Afetos: Participação das Plantas na Composição de Médiuns Umbandistas. Boletim do Musen Paraense Emílio Goeldi. Ciências Humanas 12:855-868. DOI:10.1590/1981.81222017000300011.

Carlessi, P. C. 2015. Dimensão e Fluxo Material das Plantas em um Terreiro de Umbanda. Ava Revista de Antropologia 27:47-62.

Barros, J. F. P. D., and E. Napoleão 1999. Ewé Òrișà: Uso Litúrgico e Terapêutico dos Vegetais nas Casas de Candomblé Jêje-Nagô. Bertrand Brazil, Rio de Janeiro, Brazil.

Castor, K. G. 2015. Gira mundos: A Educação Ambiental no Mito e o Mito na Educação Ambiental. Doctoral Dissertation, Department of Education, Federal University of Espírito Santo, Vitória, Brazil. Available at: http://repositorio.ufes.br/ bitstream/10/1306/1/Tese $\% 20$ Katia $\% 20$ Gon $\%$ c3\%a 7alves.pdf. Accessed on September 3, 2019.

Daly, L., K. French, T. L. Miller, and L. Nic Eoin. 2016. Integrating Ontology into Ethnobotanical Research. Journal of Ethnobiology 36:1-9. DOI:10.2993/0278-0771-36.1.1.
DeVore, J. 2017. The Mind of the Copaíba Tree: Notes on Extractivism, Animism, and Ontology from Southern Bahia. Ethnobiology Letters 8:115-124. DOI:10.14237/ebl.8.1.2017.965.

Fidalgo, O., and V. L. R. Bononi. 1989. Técnicas de Coleta, Preservação e Herborização de Material Botânico. Governo do Estado de São Paulo, Secretaria do Meio Ambiente, Instituto de Botânica, São Paulo, Brazil.

Latour, B. 1987. Science in Action: How to Follow Scientists and Engineers Through Society. Harvard University Press, Cambridge, MA.

Latour, B. 1999. Pandora's Hope: Essays on the Reality of Science Studies. Harvard University Press, Cambridge, MA.

Latour, B., and S. Woolgar. 2013. Laboratory Life: The Construction of Scientific Facts. Princeton University Press, Princeton, NJ.

Ludwig, D. 2018. Does Cognition Still Matter in Ethnobiology? Ethnobiology Letters 9:269-275. DOI:10.14237/ebl.9.2.2018.1350.

Mello, M. L., and S. S. Oliveira. 2013. Health, Religion and Culture: A Dialogue Based on Afro-Brazilian Customs. Saúde e Sociedade 22:1024-1035. DOI:10.1590/S0104-12902013000400006.

Moutinho-Da-Costa, L. 2013. Racismo Ambiental na Conservação da Natureza. In A Floresta: Educação, Cultura e Justiça Ambiental, edited by A. Mello Corrêa, L. Moutinho-da-Costa, and J. F. P. Barros, pp. 203234. Garamond Universitária e FAPERJ, Rio de Janeiro, Brazil.

Oliveira, J. C. 2012. Entre Plantas e Palavras. Modos de Constituição de Saberes Entre os Wajäpi (AP). Doctoral Dissertation, Department of Anthropology, University of São Paulo, São Paulo-Brazil. Available at: $\quad$ http://www.teses.usp.br/teses/disponi veis/8/8134/tde-22082012-100255/pt-br.php. Accessed on September 3, 2019.

Rêgo, J. 2006. Territórios do Candomblé : A Desterritorialização dos Terreiros na Região Metropolitana de Salvador, Bahia. GeoTextos 2:3185. DOI:10.9771/1984-5537geo.v2i2.3038.

Rocha, J. A., E. Neffa, and L. Leandro. 2014. The Contribution of Ethnobotany in the Elaboration of Public Policies on the Environment: A Challenge in 
Bringing. Ambiciência 10:43-64. DOI:10.5935/ ambiencia.2014.01.04.

Silva, V. G. 2005. Candomblé e Umbanda: Caminhos da Devoção Brazileira: Selo Negro, São Paulo, Brazil.
Voeks, R. A. 1997. Sacred Leaves of Candomblé: African Magic, Medicine, and Religion in Brazil. University of Texas Press, Austin, TX. 